\title{
Genetic diversity and virulence genes in Streptococcus uberis strains isolated from bovine mastitis
}

\section{Diversidade genética e genes de virulência em amostras de Streptococcus uberis isolados de mastite bovina}

\author{
Rafael Ambrósio Loures ${ }^{1}$; Ulisses de Pádua Pereira ${ }^{2}$; Glei dos Anjos de Carvalho- \\ Castro $^{3}$; Gláucia Frasnelli Mian ${ }^{4}$; Dircéia Aparecida da Costa Custódio ; Juliana \\ Rosa da Silva ${ }^{6}$; Geraldo Márcio da Costa ${ }^{7 *}$
}

\section{Resumo}

\begin{abstract}
A mastite é uma das doenças infecciosas mais onerosas em bovinos leiteiros em todos os continentes. Trata-se de uma doença de cunho multifatoral causada por diferentes microrganismos, incluindo vírus, leveduras, algas, parasitas e várias espécies de bactérias. Entre as bactérias, Streptococcus uberis destacase como um importante agente ambiental, responsável por uma grande variedade de infecções clínicas e subclínicas da glândula mamária, especialmente em sistemas de produção intensivos. Apesar da crescente importância de S. uberis na etiologia da mastite bovina, existem poucos estudos sobre a diversidade populacional e fatores de virulência deste patógeno em rebanhos leiteiros brasileiros.Os objetivos do presente estudo foram investigar as características de virulência e a epidemiologia molecular de $S$. uberis isolados de mastite bovina em rebanhos brasileiros, utilizando-se a PCR e a eletroforese em gel de campo pulsado (PFGE). Para tal, 46 amostras de $S$. uberis isoladas de mastite bovina em 26 rebanhos leiteiros de uma mesma mesorregião brasileira foram avaliadas quanto à diversidade populacional por eletroforese em gel de campo pulsado (PFGE), utilizando-se a enzima Smal. Além disso, foi realizada PCR para detectar os genes de virulência pauA e $s k c$, que codificam ativadores de plasminogênio, e do gene sua, que codifica uma proteína de adesão às celulas epiteliais da glândula mamária. Nossos resultados mostraram uma alta diversidade genética na população estudada, com vários padrões de PFGE, e uma elevada frequência dos genes de virulência pesquisados: sua $(100 \%)$, pauA $(91 \%)$ e $s k c$ (91\%). A alta frequência dos genes $s k c$, pauA e sua sugere a importância destes fatores de virulência para S. uberis na colonização da glândula mamária bovina. Estudos moleculares e genéticos sobre este agente podem contribuir muito para melhorar o conhecimento sobre a patogenia, permitindo identificar moléculas que tenham papel relevante no estabelecimento da infecção, fornecendo informações importantes para a adoção de medidas mais eficazes para a prevenção e o controle da mastite bovina.
\end{abstract}

Palavras-chave: Doenças de bovinos. Estreptococos ambientais. Infecções intramamárias. PFGE. Virulência bacteriana.

\footnotetext{
1 Discente, Curso de Mestrado, Programa de Pós-Graduação em Ciências Veterinárias, Departamento de Medicina Veterinária, Universidade Federal de Lavras, UFLA, Lavras, MG, Brasil. E-mail: rafaelvet@gmail.com

2 Prof., Departamento de Medicina Veterinária Preventiva, Universidade Estadual de Londrina, UEL, Londrina, PR, Brasil. E-mail: upaduapereira@uel.br

3 Pós-Doutoranda, Departamento de Medicina Veterinária, UFLA, Lavras, Prof ${ }^{a}$. Universidade do Vale do Rio Verde Três Corações, MG, Brasil. E-mail: gleicarv@yahoo.com.br

4 Prof ${ }^{a}$, Departamento de Medicina Veterinária, UFLA, Lavras, MG, Brasil. E-mail: glaucia@dmv.ufla.br

${ }^{5}$ Bióloga, Departamento de Medicina Veterinária, UFLA, Lavras, MG, Brasil. E-mail: dirceia@dmv.ufla.br

6 Discente, Curso de Doutorado, Programa de Pós-Graduação em Ciências Veterinárias, Departamento de Medicina Veterinária, UFLA, Lavras, MG, Brasil. E-mail: ju rosa_silva@hotmail.com

Prof. Orientador, Departamento de Medicina Veterinária, UFLA, Lavras, MG, Brasil. E-mail: gmcosta@dmv.ufla.br

* Author for correspondence
}

Received: Nov. 24, 2016 Approved: Apr. 24, 2017 


\begin{abstract}
Mastitis is one of the most common and costly infectious diseases in dairy cattle worldwide. This is a multifactorial illness caused by different microorganisms, including virus, yeasts, algae, parasites, and several species of bacteria. Among these bacteria, Streptococcus uberis is an important environmental pathogen that is responsible for a large range of clinical and subclinical mammary infections, especially in intensively managed herds. Despite the increasing importance of this pathogen in the etiology of bovine mastitis, data on its virulence and diversity in Brazilian dairy herds are scarce. The aims of the present study were to investigate the virulence characteristics of $S$. uberis isolated from bovine mastitis and to assess the molecular epidemiology of the Brazilian isolates using pulsed-field gel electrophoresis (PFGE). In this work, 46 strains of S. uberis isolated from bovine mastitis from 26 Brazilian dairy herds were evaluated regarding their genetic diversity by PFGE using with the SmaI enzyme. Additionally, the presence of the virulence genes $s k c$ and $p a u A$, which encode plasminogen activators, and the gene sua, which encodes an adhesion molecule in mammary epithelial cells, were assessed by PCR. Our results showed a high genetic diversity in the population, displaying many different patterns in the PFGE analysis. A high proportion of strains was positive for virulence genes in the sampled population (sua [100\%], pauA [91\%], and skc [91\%]). The high frequency of $s k c, p a u A$, and sua genes among the studied strains suggests the importance of these virulence factors, possibly helping $S$. uberis in the colonization of the bovine mammary gland. Surveys of the genetic and molecular characteristics of this pathogen can improve our knowledge of bacterial activity and identify molecules that have roles in the establishment of the infection. This might help in the development of more effective measures to control and prevent bovine mastitis.
\end{abstract}

Key words: Bovine diseases. Environmental Streptococci. Intramammary infections. PFGE. Streptococci virulence.

\section{Introduction}

Despite all of the progress made to prevent and control mastitis in recent decades, it remains the most prevalent infectious and economically detrimental disease in dairy cattle worldwide (ACOSTA et al., 2016; KEEFE, 2012; PAUL; GANGULY, 2014; SAAB et al., 2014; VLIEGHER et al., 2012). The economic impact of bovine mastitis results from the drop in milk production, and milk discarded from animals in treatment, drug expenditures, the early replacement of cows, and eventually, the death of diseased animals. Bovine mastitis alters the physicochemical characteristics of the milk, such as reducing fat and casein, in addition to increasing somatic cell counts. This leads to economic losses in industries and to depreciation in the nutritional and organoleptic characteristics of dairy products (PETON; LE LOIR, 2014). Additionally, this illness causes economic losses for producers due to presence of antibiotic residues in the milk caused by it indiscriminate use, beyond the emergence of resistant bacteria which can spread among the livestock on farms (VLIEGHER et al., 2012).

The major bovine mastitis pathogens are the bacteria Escherichia coli, Klebsiella pneumoniae, Streptococcus agalactiae, Staphylococcus aureus, and Streptococcus uberis (S. uberis) (JAIN et al., 2012; KEEFE, 2012; RATO et al., 2013; ZADOKS et al., 2011). Mastitis management programs involve teat disinfection after milking, dry cow therapy, maintenance of milking equipment, and segregation and discard of chronically infected animals. These measures have enabled the effective control of intramammary infections (IMI) caused by contagious pathogens. In contrast, these strategies have low effects on the incidence of environmental mastitis (ALMEIDA et al., 2015; BRADLEY et al., 2002; JAYARAO et al., 1991; PHUEKTES et al., 2001).

S. uberis is one of the most frequentenvironmental pathogens causing clinical and subclinical bovine 
mastitis. It has a significant impact on cow's udder health, milk quality, and herd productivity (SHOME et al., 2012). According Pullinger et al. (2006), this bacterium is one of the main mastitis causative pathogens in many countries, and it has been associated with economic losses for dairy producers.

Surveys of dairy cattle worldwide showed an increase in mastitis caused by S. uberis, especially in intensively managed herds (ALMEIDA et al., 2006; COSTA unpublished data; DOUGLAS et al., 2000; PHUEKTES et al., 2001). Despite the economic impact caused by this bacterium in well-managed dairy herds, the pathogenesis of the disease and the relationship between genetic diversity and virulence genes is poorly studied. This constitutes a major obstacle for the development of control strategies (ALMEIDA etal., 2006). One strategy for controlling S. uberis mastitis involves cow vaccination. A successful vaccine against $S$. uberis should confer broad protection against the predominant strains. For this, additional epidemiological data and an understanding of virulence mechanisms in this bacterium are necessary (PERRIG et al., 2015; SHOME et al., 2012).

Several molecular methods based on genotyping have been used to study the population diversity of $S$. uberis (LASAGNO et al., 2011; RATO et al., 2008; WANG et al., 2013; ZADOKS et al., 2003). These approaches may permit the development of more effective control measures for this microorganism. Among the different molecular typing methods, the Pulsed Field Gel Electrophoresis (PFGE) technique has been used to study pathogens involved in the etiology of bovine mastitis because it is highly discriminatory and highly reproducible (BASEGGIO et al., 1997; DOUGLAS et al., 2000; LASAGNO et al., 2011; PHUEKTES et al., 2001; RATO et al., 2008, 2013). According to Shome et al. (2012), PFGE is the technique of choice for short-term or local epidemiological analyses. Aside from the advances in molecular tools, there are few reports about the population diversity and virulence profiles of the $S$. uberis strains that cause bovine mastitis in Brazilian dairy herds.

Among the virulence genes previously described in $S$. uberis, genes that encode plasminogen activators have key roles in the degradation of fibrin and other extracellular matrix proteins that bind and help remodel tissues (LUTHER et al., 2008). In Streptococci, these enzymes are known as streptokinases, including PauA, which is specific for S. uberis (JOHNSEN et al., 1999; WARD; LEIGH, 2004). Another important virulence factor is the SUAM protein, which has been shown to be necessary for adhesion and internalization of $S$. uberis into mammary epithelial cells (LUTHER et al., 2008; PATEL et al., 2009). Although bovine IMI caused by $S$. uberis are increasing, there are few studies about this pathogen in Brazilian dairy herds. Therefore, the aims of this study were to perform a molecular characterization of $S$. uberis isolated from mastitis in bovine dairy herds from south Minas Gerais State, a milk-producing region in southeastern Brazil.

\section{Material and Methods}

Bacterial strains - A total of 46 S. uberis strains obtained from 26 dairy farms, which were located in a milk-producing mesoregion in the south region of Brazil, were used in this study. The strains were phenotypically characterized. Briefly, biochemical tests including aesculin and hippurate hydrolysis, production of acid from inulin, as well as hemolysis, Christie-Atkins-Munch-Petersen (CAMP) test were performed (KHAN et al., 2003; OLIVER et al., 2004; WATTS, 1988). The reference strain ATCC 700407 and NEM316 were used in assays as a positive and negative control, respectively.

DNA extraction - Total DNA was extracted using the Axygen DNA Mini-prep ${ }^{\circledR}$ Kit (Axygen, USA) according to the manufacturer's instructions.

Specific PCR and detection of virulence genes - The strains classified as $S$. uberis in phenotypic 
tests were submitted to genotypic identification. This involved performing S. uberis-specific PCR according to Hassan et al. (2001). The strains confirmed to be $S$. uberis by genotyping were screened for the most relevant virulence genes (pauA, skc, and sua) using primers described by Luther et al. (2008), Johnsen et al. (1999) and Rosey et al. (1999) (Table 1). The amplification products were analyzed on a $1.5 \%(\mathrm{w} / \mathrm{v})$ agarose gel by electrophoresis with $1 \times$ Tris-acetate buffer (0.04 $\mathrm{M}$ Tris-acetate, $\mathrm{pH} 8.4,1 \mathrm{mM}$ EDTA). Bands were visualized with a UV transilluminator after staining with GelRed (Biotium, USA). A 100-bp DNA molecular ladder (New England Biolabs, USA) was used in the electrophoresis, and gel images were obtained.

Table 1. Primers used for screening of Streptococus uberis.

\begin{tabular}{lll}
\hline Genes & Primers & References \\
\hline \multirow{2}{*}{ 16S rDNA } & STRU-UbI 5'TAAGGAACACGTTGGTTAAG 3' & Hassan et al. (2001) \\
\multirow{2}{*}{ pauA } & STRU-UbII 5'TCCAGTCCTTAGACCTTCT 3' & \\
\multirow{2}{*}{ skc } & P38 5'AATAACCGGTTATGATTCCGACTTCCGACTAC3' & Rosey et al. (1999) \\
& P39 5'AAAATTTACTCGAGACTTCCTTTAAGG' & \\
sua & SKC-I 5'GTCATTTGGTAGGAGTGGCTG 3' & Johnsen et al. (1999) \\
& SKC-II 5'TGGTTGATATAGCACTTGGTGAC3' & \\
& 5'-GCTGAAAATGCTAAAGAAGAAC-3' & Luther et al. (2008) \\
\hline
\end{tabular}

4. PFGE cluster analysis. PFGE analysis of the $46 \mathrm{~S}$. uberis isolates was performed using modifications of previously described methods (PHUEKTES et al., 2001). Briefly, S. uberis isolates were incubated in BHI broth (Difco, Houston, TX) at $37^{\circ} \mathrm{C}$ overnight until they reached stationary phase. The cells were harvested by centrifugation at 13,000 $\times g$ for $1 \mathrm{~min}$ and washed three times with $1 \mathrm{~mol} / \mathrm{L} \mathrm{NaCl}$ and $10 \mathrm{mmol} / \mathrm{L}$ Tris- $\mathrm{HCl}$ ( $\mathrm{pH}$ 7.6). Culture samples were then centrifuged, resuspended with $100 \mu \mathrm{l}$ of the same solution, mixed with an equal volume of molten 2\% (wt/vol) low-melt agarose (SeaPlaque; FMC Bioproducts, Rockland, ME), and poured into 100 $\mu 1$ molds. When solidified, plugs were incubated at $37^{\circ} \mathrm{C}$ for $18 \mathrm{~h}$ in lysis buffer containing $25 \mathrm{U} / \mathrm{mL}$ mutanolysine and $1 \mathrm{mg} / \mathrm{mL}$ lysozyme. Cells were subsequently transferred into ESP buffer $(0.5 \mathrm{~mol} / \mathrm{L}$ EDTA [pH 9.2], 1\% Sarkosyl, $1 \mathrm{mg} / \mathrm{mL}$ proteinase $\mathrm{K}$ ) and incubated at $50^{\circ} \mathrm{C}$ for $72 \mathrm{~h}$. The plugs were then washed five times for 45 min each with $1 \times$ TE buffer $(10 \mathrm{mmol} / \mathrm{L}$ Tris- $\mathrm{HCl}[\mathrm{pH} 8]$ and $1 \mathrm{mmol} / \mathrm{L}$ EDTA [pH 8]). Samples were then stored at $4^{\circ} \mathrm{C}$ in $1 \mathrm{~mL}$ of $0.5 \mathrm{~mol} / \mathrm{L}$ EDTA [pH 8] until use. A 3-mm slice of each agarose plug was washed five times with $100 \mu$ of 1.2 restriction endonuclease buffer (MBI Fermentas) for $45 \mathrm{~min}$ each on ice. The slices were then digested in $100 \mu \mathrm{l}$ of $1 \times$ fresh restriction endonuclease solution containing $12 \mathrm{U}$ of SmaI (Amersham Biosciences, UK) at $30^{\circ} \mathrm{C}$ for $18 \mathrm{~h}$. After incubation, the fragments were separated using a clamped homogeneous electric field device (CHEF DRII, Bio-Rad, Hercules, CA). The restriction fragments were loaded into the wells of $1 \%(\mathrm{wt} / \mathrm{vol})$ agarose gels in $0.5 \times$ TBE $(89 \mathrm{mmol} / \mathrm{L}$ Tris- $\mathrm{HCl}, 89$ $\mathrm{mmol} / \mathrm{L}$ boric acid, and $2 \mathrm{mmol} / \mathrm{L}$ EDTA, $\mathrm{pH} 8.3$ ) at $14^{\circ} \mathrm{C}$. Lambda ladder PFG Marker (New England Biolabs, USA) was included as a molecular size standard. The gel was run at $6 \mathrm{~V} / \mathrm{cm}$ for $23 \mathrm{~h}$ with an initial pulse time of $1 \mathrm{~s}$ and a final pulse time of 30 s. The gels were stained with ethidium bromide $(0.5$ $\mathrm{mg} / \mathrm{L}$ ) for $1 \mathrm{~h}$, and photographed under UV light. 
The gel bands were analyzed using GelAnalyser software. Isolates generating more than three different restriction patterns were classified as unrelated isolates (with different letters). The test was repeated twice to ensure reproducibility.

Images were analyzed using Gel ComparII software $^{\circledR}$ (Applied Maths, Belgium) to create dendrograms of the genetic relationships among the strains from different hosts. Briefly, bands were automatically assigned by the computer, and they were then corrected manually after the original images were checked and evaluated visually. Only clearly resolved bands were counted. The Dice coefficient $(95 \%)$ was used to analyze the similarities of the banding patterns. The unweighted pair group method with average linkages (UPGMA) was used for cluster analysis. Isolates that showed $100 \%$ similarity were considered indistinguishable, and isolates with similarity $>80 \%$ were considered clonally related (SINGH et al., 2006).

5. Data analysis - The discriminatory index for the PFGE technique was calculated using Simpson's index of diversity (HUNTER; GASTON, 1988).

\section{Results and Discussion}

S. uberis is a very important environmental pathogen that causes bovine mastitis (ALMEIDA et al., 2006; LASAGNO et al., 2011; PERRIG et al., 2015). According to Hillerton and Berry (2003), environmental Streptococci are responsible for about one-third of all clinical mastitis cases worldwide, and IMI caused by these bacteria is closely associated with poor environmental or milking hygiene conditions. Although the bovine mastitis caused by this agent has been growing in prevalence, there is little information about its epidemiology and virulence in Brazilian herds.

Conventional control measures based on milking hygiene and antibiotic therapy are useful to reduce most contagious pathogens. However, these are often ineffective for the control of mastitis caused by $S$. uberis. The development of vaccines has been the focus of control strategy development. However, the high level of genetic variability of S. uberis, which frequently involves several virulence factors, has been a serious obstacle in the development of effective vaccines. In this context, epidemiological studies are extremely useful for determining the frequency and distribution of bacterial types associated with IMI, and for identifying target molecules for the development of immunogens and therapeutic agents (PERRIG et al., 2015). In the present study, molecular tests aiming to detect virulence factors and PFGE were used to molecular characterization of the $S$. uberis strains isolated from cows belonging to herds located in the south of Minas Gerais State, an important milk-producing region of the country.

Gene-specific PCR assays identified the strains as $S$. uberis in accordance with previous phenotypic tests. Results revealed that not all virulence genes were present in the strains, but at least one was found in each strain. PCR analysis detected the sua gene in $100 \%(n=45)$ of the strains, which was the most common gene found in the screened isolates. The high frequency of the sua gene in this study was similar to that related by other researchers (LUTHER et al., 2008; PERRIG et al., 2015; YUAN et al., 2014) in strains of S. uberis isolated from geographically diverse locations. However, our results were different from previous studies that showed slightly lower frequencies for the sua gene: $83.3 \%$ in Argentina (REINOSO et al., 2011) and $84.6 \%$ in India (SHOME et al., 2012).

The protein SUAM, encoded by the sua gene, increases the bacterial adherence in the bovine mammal epithelial cells. Invasion, persistence, and internalization are up regulated by binding of SUAM to lactoferrin, which is primarily synthesized in those cells (ALMEIDA et al., 2006; CHEN et al., 2011; LUTHER et al., 2008). This gene is reported to be highly conserved (LUTHER et al., 2008; PERRIG et al., 2015), supporting its potential utility for the development of vaccines. Recent studies of 
vaccines targeting the adhesion molecule SUAM showed that antibodies against this protein facilitate clearance of the pathogen, reducing colonization, clinical symptoms of mastitis, and new IMI (ALMEIDA et al., 2015).

The plasminogen activator genes pauA and $s k C$ were found at high frequencies in the strains evaluated $(91 \%, \mathrm{n}=43)$. Likewise, similar results were obtained for $S$. uberis isolated from mastitis samples in other geographic regions (KHAN et al., 2003; ROSEY et al., 1999; SHOME et al., 2012; WARD; LEIGH, 2004). Perrig et al. (2015) related the presence of the pauA gene in $94.9 \%$ of the strains studied. Other studies conducted in India showed that the prevalence of the pauA gene was $100 \%$ (KHAN et al., 2003; SHOME et al., 2012). In contrast, Reinoso et al. (2011) showed a slower frequency $(61.5 \%)$ of this gene in strains isolated from bovine mastitis samples in Argentina. According to these authors, the low frequency of this gene could be explained by the presence of other activators of plasminogen. A few studies assessed the gene $s k C$ in $S$. uberis, but all of these reports found its frequency to be similar to that of pauA (JOHNSEN et al., 1999, KHAN et al., 2003, REINOSO et al., 2011, SHOME et al., 2012).

Controversies exist regarding these two genes in the literature. While some authors suggest that they are distinct genes, others used sequencing analyses to show that they are the same (ROSEY et al., 1999; KHAN et al., 2003; REINOSO et al., 2011; SHOME et al., 2012). In silico analyses of the sequences of these genes deposited in GenBank suggest these genes are the same, but future studies that involve direct sequencing of the genes are necessary to confirm this hypothesis. The presence of virulence genes with this function increases the pathogenicity of the strains because activation of host plasminogen produces a serine protease (plasmin) that is a receptor for bacterial pathogens. This augments the ability of these bacteria to colonize a host (WARD et al., 2009). Additionally, plasminogen activation has been proposed to be an important mechanism for $S$. uberis to obtain nutrients (WARD; LEIGH, 2004). Plasminogen activators are proteases capable of activating plasmin, which degrades milk proteins into small peptides and free amino acids, which are used by the pathogen as a nitrogen source for its growth (PERRIG et al., 2015).

The high frequency of the pauA/skc and sua genes observed in this study suggests that these factors may play a crucial role in the pathogenesis of $S$. uberis, nevertheless other virulence factors could be involved. According to Perrig et al. (2015), the sua and pauA genes are highly conserved, and they are present in most $S$. uberis strains isolated in different countries. This suggests the possibility that these virulence factors could be used as vaccine components against $S$. uberis, despite the high genetic variability observed for this bacterial species.

Among the strains evaluated, 35 different patterns were observed in PFGE, which were identified as I, II, and III-XXXV (Figure 1). PFGE demonstrated a high discriminatory index $(0.9889)$ in accordance with previous studies (DOUGLAS et al., 2000; LASAGNO et al., 2011; PHUEKTES et al., 2001; RATO et al., 2008, 2013). Four pulse-types found by PFGE (VI, VII-a, VIII, and IX) showed two strains with similar patterns that were classified as having identical restriction patterns (Figure 1). These strains were obtained from different animals in the same herd. Additionally, three other different subtypes were found in these herds, amounting to five subtypes infective in seven cows, pointed the high diversity of $S$. uberis. Our findings suggest that the transmission may also occur during milking, beyond the environmental transmission, according Rato et al. (2008). 
Figure 1. Pulse Field Gel Electrophoresis from 46 strains of Streptococcus uberis isolated from bovine mastitis in dairy herds from south Minas Gerais State.

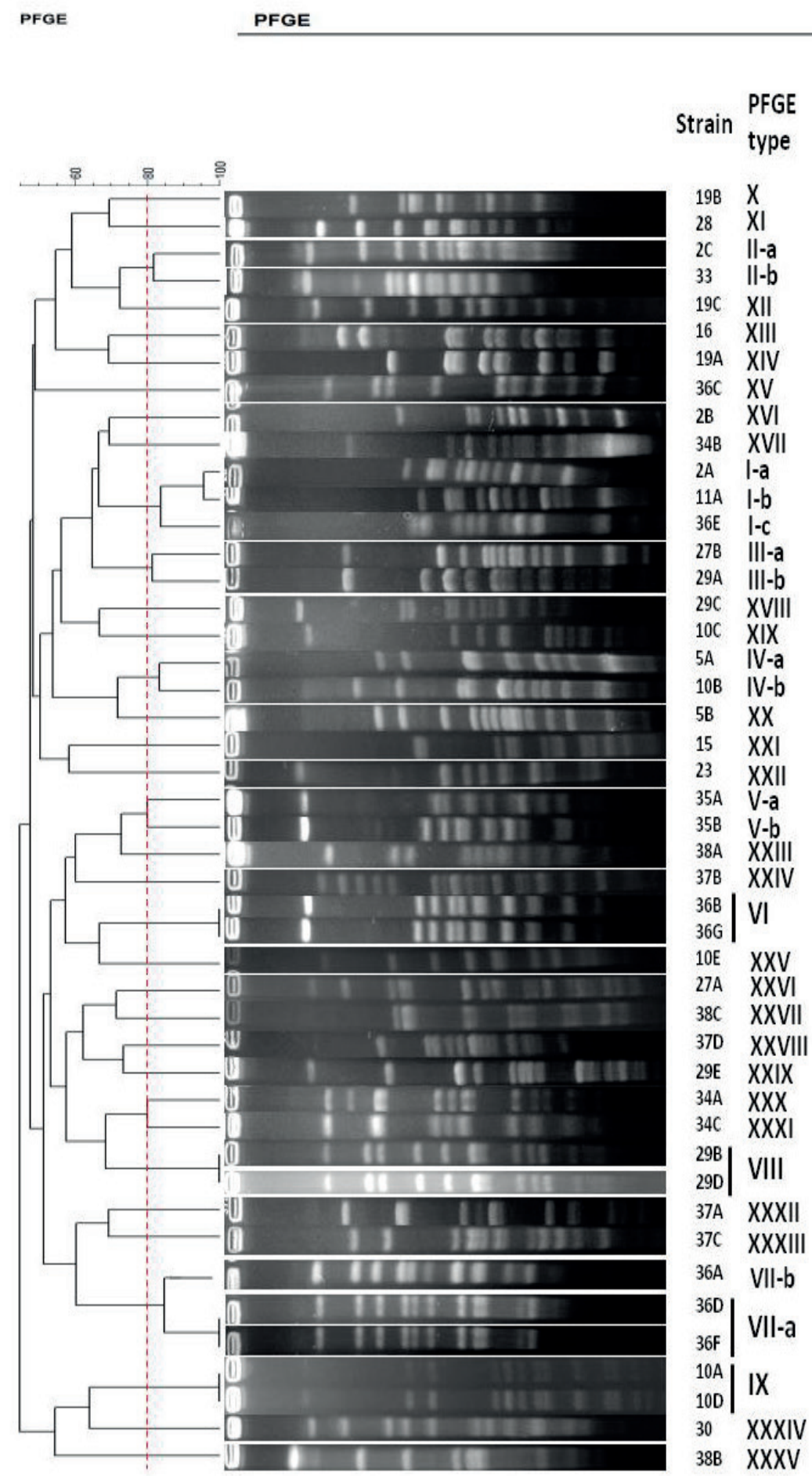


In our study, strains of clinical and subclinical mastitis cases were used; however, the small sample size makes it impossible to make inferences about the relationship between the severity of the disease that can be related to several conditions pertaining to the host, such as udder health, nutrition, genetic diseases, and lactation stage (JAYARAO et al., 1991). Moreover, it was shown that this bacterium may persist, triggering subclinical mastitis. It could also prove highly resistant to antimicrobial treatments (PULLINGER et al., 2007; ZADOKS et al., 2003).

Strains with the same or similar genetic profile were only observed in four herds (herds 10, 29, 35, and 36). Interestingly, herd 29 harbored two profiles with two strains per profile (profiles III and VIII), and herd 36 had two strains of the profile VI and three strains of the profile VII (Figure 1). Thus, most of the strains from each herd were classified as unrelated pulse-types. Previous studies showed similar results for isolates from clinical mastitis, suggesting that these strains are the predominant ones in the environment. Although $S$. uberis is predominantly an environmental pathogen, its transmission could be from animal to animal as a contagious mastitis pathogen (ABUREEMA et al., 2014; DOUGLAS et al., 2000; LASAGNO et al., 2011).

Finally, 26 strains were classified as unrelated isolates, consisting of a PFGE profile with only one strain. This indicates high population diversity among the $S$. uberis strains isolated from bovine mastitis in accordance with previous studies (LASAGNO et al., 2011; HAENNI et al., 2010; REINOSO et al., 2015; WANG et al., 1999, 2013). As discussed above, this diversity could be associated with environmental adaptations of this pathogen and its capacity to infect cows.

Similar PFGE results were obtained in previous studies worldwide. Reinoso et al. (2015) evaluated the genotypic relationships among $40 \mathrm{~S}$. uberis strains isolated from bovine mastitis by PFGE. They identified 17 different PFGE patterns, showing that distinct strains were present within and among the herds. Some of the predominant clones infecting some herds displayed an identical PFGE type. Lasagno et al. (2011) identified 18 PFGE patterns with $90 \%$ similarity among $32 \mathrm{~S}$. uberis isolated from bovine mastitis samples. They observed a great diversity of virulence profiles and several PFGE patterns among the dairy herds studied. Interestingly, S. uberis strains with the same PFGE pattern displayed different virulence profiles. In another study, Perrig et al. (2015) evaluated 137 strains of $S$. uberis by PFGE, and observed 61 different PFGE types. They found that 11 of these strains isolated from different cows in the same herd showing identical restriction patterns.

The results of this study showed that the $S$. uberis population is very heterogeneous, displaying multiple PFGE patterns. This suggests an opportunistic behavior, and that this pathogen might cause IMI due to contamination of the mammary gland as a result of poor environmental hygiene conditions. However, the presence of strains that have clonal characteristics within a single herd, which was observed in this study and previous ones, suggests a common environmental source of infection of the mammary gland or that pathogen dissemination might also occur by indirect transmission during milking.

To our knowledge, this is the first report describing virulence and genotypic characteristics of $S$. uberis strains associated with mastitis in dairy cows in Brazil.

\section{Conclusions}

In conclusion, our study showed that the $S$. uberis strains isolated from bovine mastitis in dairy cattle in Southeastern Brazil were a diverse bacterial population according PGFE analysis. The virulence genes screened were present at high frequencies in the strains evaluated, suggesting a potential role in the virulence of this bacterium. 
Because of the high population diversity and the potential for IIM caused by S. uberis, improvements in the management of dairy herds are necessary to control this pathogen.

\section{Acknowledgments}

This work was supported by grant FAPEMIG BPD-00261/14. We would like to thank FAPEMIG and CAPES for the student fellowship.

This study adheres to the guidelines of the ethical committee for animal research. The study was performed on bacterial strains isolated from milk samples received by our routine diagnostic laboratory without directly involving animals or humans in the assays.

\section{Competing Interest Statement}

The authors declare no competing financial interests.

\section{References}

ABUREEMA, S.; SMOOKER, P.; MALMO, J.; DEIGHTON, M. Molecular epidemiology of recurrent clinical mastitis due to Streptococcus uberis: Evidence of both an environmental source and recurring infection with the same strain. Journal of Dairy Science, Champaign, v. 97, n. 1, p. 285-290, 2014.

ACOSTA, A. C.; Silva, L. B. G.; MEdeIROS, E. S.; PINHEIRO-JÚNIOR, J. W.; MOTA, R. A. Mastites em ruminantes no Brasil. Pesquisa Veterinária Brasileira, Seropédica, v. 36, n. 7, p. 565-573, 2016.

ALMEIDA, R. A.; KERRO-DEGO, O.; PRADO, M. E.; HEADRICK, S. I.; LEWIS, M. J.; SIEBERT, L. J.; PIGHETTI, G. M.; OLIVER, S. P. Protective effect of anti-SUAM antibodies on Streptococcus uberis mastitis. $B M C$ Veterinary Research, Londres, v. 46, n. 133, p. 1-6, 2015.

ALMEIDA, R. A.; LUTHER, D. A.; PARK, H. M.; OLIVER, S. P. Identification, isolation, and partial characterization of a novel Streptococcus uberis adhesion molecule (SUAM). Veterinary Microbiology, Barcelona, v. 115, n. 1-3, p. 183-191, 2006.
BASEGGIO, N.; MANSELL, P. D.; BROWNING, J. W.; BROWNING, G. F. Strain differentiation of isolates of streptococci from bovine mastitis by pulsed-field gel electrophoresis. Molecular and Cellular Probes, Amsterdan, v. 11, n. 5, p. 349-354, 1997.

BRADLEY, A. J. Bovine mastitis: an evolving disease. The Veterinary Journal, London, v. 164, n. 2, p. 116-128, 2002.

CHEN, X.; DEGO, O. K.; ALMEIDA, R. A.; FULLER, T. E.; LUTHER, D. A.; OLIVER, S. P. Deletion of sua gene reduces the ability of Streptococcus uberis to adhere to and internalize into bovine mammary epithelial cells. Veterinary Microbiology, Barcelona, v. 147, n. 3-4, p. 426-434, 2011.

COSTA, G. M. Data collection from veterinary microbiology laboratory of the Federal University of Lavras. [s.1.:s.n.], (Unpublished data).

DOUGLAS, V. L.; FENWICK, S. G.; PFEIFFER, D. U.; WILLIAMSON, N. B.; HOLMES, C. W. Genomic typing of Streptococcus uberis isolates from cases of mastitis, in New Zealand dairy cows, using pulsed field gel electrophoresis. Veterinary Microbiology, Barcelona, v. 75, n. 1 , p. $27-41,2000$.

HAENNI, M. Diversity and mobility of integrative and conjugative elements in bovine isolates of Streptococcus agalactiae, S. dysgalactiae subsp. dysgalactiae, and S. uberis. Applied Environmental Microbiology, Washington, v. 76, n. 24, p. 7957-7965, 2010.

HASSAN, A. A.; KHAN, I. U.; ABDULMAWJOOD, A.; LAMMLER, C. Evaluation of PCR methods for rapid identification and differentiation of Streptococcus uberis and Streptococcus parauberis. Journal of Clinical Microbiology, Barcelona, v. 39, n. 4, p. 1618-162, 2001.

HILLERTON, J. E.; BERRY, E. A. The management and treatment of environmental streptococcal mastitis. Veterinary Clinics North American Food Animal Practice, Amsterdan, v. 19, n. 1, p. 157-169, 2003.

HUNTER, P. R.; GASTON, M. A. Numerical index of the discriminatory ability of typing systems: an application of Simpson's index of diversity. Journal of Clinical Microbiology, Barcelona, v. 26, n. 11, p. 24652466, 1988.

JAIN, B.; TEWARI, A.; BHANDARI, B. B.; JHALA, M. K. Antibiotic resistance and virulence genes in Streptococcus agalactiae isolated from cases of bovine subclinical mastitis. Veterinarski Arhiv, Zagreb, v. 82, n. 5, p. 423-432, 2012.

JAYARAO, B. M.; DORÉ-JUNIOR, J. J.; BAUMBACH, G. A.; MATTHEWS, K. R.; OLIVER, S. P. Differentiation of Streptococcus uberis from Streptococcus parauberis 
by polymerase chain reaction and restriction fragment length polymorphism analysis of $16 \mathrm{~s}$ ribosomal DNA. Journal of Clinical Microbiology, Barcelona, v. 29, n. 12, p. 2774-2778, 1991.

JOHNSEN, L. B.; POULSEN, K.; KILIAN, M.; PETERSEN, P. Purification and cloning of a streptokinase from Streptococcus uberis. Infection Immunology, Washington, v. 67, n. 3, p. 1072-1078, 1999.

KEEFE, G. Update on control of Staphylococcus aureus and Streptococcus agalactiae for management of mastitis. Veterinary Clinical of Food Animal Practice, Amsterdan, v. 28, n. 2, p. 203-216, 2012.

KHAN, I. U.; HASSAN, A. A.; ABDULMAWJOOD, A.; LAMMLER, C.; WOLTER, W.; ZSCHOCK, M. Identification and epidemiological characterization of Streptococcus uberis isolated from bovine mastitis using conventional and molecular methods. Journal Veterinary Sciences, Gwanak-gu, v. 4, n. 3, p. 213-224, 2003.

LASAGNO, M. M.; REINOSO, E. B.; DIESER, S. A.; CALVINHO, L. F.; BUZZOLA, F.; VISSIO, C.; BOGNI, C. I.; ODIERNO, L. M. Phenotypic and genotypic characterization of Streptococcus uberis isolated from bovine subclinical mastitis in Argentinean dairy farms. Revista Argentina de Microbiología, Buenos Aires, v. 43, n. 3, p. 212-217, 2011.

LUTHER, D. A.; AlMEIDA, R. A.; OlIVER, S. P. Elucidation of the DNA sequence of Streptococcus uberis adhesion molecule gene (sua) and detection of sua in strains of Streptococcus uberis isolated from geographically diverse locations. Veterinary Microbiology, Barcelona, v. 128, n. 3/4, p. 304-312, 2008.

OLIVER, S. P.; LEWIS, M. J.; GILLESPIE, B. E.; DOWLEN, H. H.; JAENICKE, E.; ROBERTS, R. K. Microbiological procedures for the diagnosis of bovine udder infection and determination of milk quality. $4^{\text {th }} \mathrm{ed}$. Verona: NMC - National Mastitis Council, 2004. 46 p.

PATEL, D.; ALMEIDA, R. A.; DUNLAP, J. R.; OLIVER, $\mathrm{S}$. P. Bovine lactoferrin serves as a molecular bridge for internalization of Streptococcus uberis into bovine mammary epithelial cells. Veterinary Microbiology, Barcelona, v. 137, n. 3/4, p. 297-301, 2009.

PAUL, I.; GANGULY, S. Bovine mastitis, an economically important bacterial infection of udder in cattle: A review. Indian Journal Scientific Research and Technology, Cantt, v. 2, n. 2, p. 1-2, 2014.

PERRIG, M. S.; AMBROGGIO, M. B.; BUZZOLA, F. R.; MARCIPAR, I. S.; CALVINHO, L. F.; VEAUTE, C. M.; BARBAGELATA, M. S. Genotyping and study of the pauA and sua genes of Streptococcus uberis isolates from bovine mastitis. Revista Argentina de Microbiología, Buenos Aires, v. 47, n. 4, p. 282-294, 2015.

PETON, V.; LE LOIR, Y. Staphylococcus aureus in veterinary medicine. Infection, Genetics and Evolution, Amsterdan, v. 21, p. 602-615, 2014.

PHUEKTES, P.; MANSELL, P. D.; DYSON, R. S.; HOOPER, N. D.; DICK, J. S.; BROWNING, G. F. Molecular epidemiology of Streptococcus uberis isolates from dairy cows with mastitis. Journal of Clinical Microbiology, Barcelona, v. 39, n. 4, p. 1460-1466, 2001.

PUllingER, G. D.; COFFEY, T. J.; MAIDEN, M. C.; LEIGH, J. A. Multilocus sequence typing analysis reveals similar populations of Streptococcus uberis are responsible for bovine intramammary infections of short and long duration. Veterinary Microbiology, Barcelona, v. 119, n. 2-4, p. 194-204, 2007.

PULLINGER， G. D.; LÓPEZ-BENAVIDES, M.; COFFEY, T. J.; WILLIAMSON, J. H.; CURSONS, R. T.; SUMMERS, E.; LACY-HULBERT, J.; MAIDEN, M.; LEIGH, J. A. Application of Streptococcus uberis multilocus sequence typing: analysis of the population structure detected among environmental and bovine isolates from New Zealand and the United Kingdom. Applied and Environmental Microbiology, Washington, v. 72, n. 2, p. 1429-1436, 2006.

RATO, M. G.; BEXIGA, R.; FLORINDO, C.; CAVACO, L. M.; VILELA, C. L.; SANTOS-SANCHES, I. Antimicrobial resistance and molecular epidemiology of streptococci from bovine mastitis. Veterinary Microbiology, Barcelona, v. 161, n. 3-4, p. 286-294, 2013.

RATO, M. G.; BEXIGA, R.; NUNES, S. F.; CAVACO, L. M.; SANTOS-SANCHES, I. Molecular epidemiology and population structure of bovine Streptococcus uberis. Journal of Dairy Science, Champaign, v. 91, n. 12, p. 4542-4551, 2008.

REINOSO, E. B.; LASAGNO, M. C.; DIESER, S. A.; ODIERNO, L. M. Distribution of virulence-associated genes in Streptococcus uberis isolated from bovine mastitis. FEMS Microbiology Letter, Holanda do Sul, v. 318, n. 2, p. 183-188, 2011.

REINOSO, E. B.; LASAGNO, S. A.; ODIERNO, L. M. Genetic patterns of Streptococcus uberis isolated from bovine mastitis. Revista Argentina de Microbiologia, Buenos Aires, v. 47, n. 2, p. 108-111, 2015.

ROSEY, E. L.; LINCOLN, R. A.; WARD, P. N.; YANCEY JUNIOR., R. J.; LEIGH, J. A. PauA: a novel plasminogen activator from Streptococcus uberis. FEMS Microbiology Letters, Holanda do Sul, v. 178, n. 1, p. 27-33, 1999. 
SAAB, A. B.; ZAMPROGNA, T. O.; LUCAS, T. M.; MARTINI, K. C.; MELlO, P. L.; SIlVA, A. V. MARTINS, L. A. Prevalence and etiology of bovine mastitis in the Nova Tebas, Paraná. Semina: Ciências Agrarias, Londrina, v. 35, n. 2, p. 835-843, 2014.

SHOME, B. R.; BHUVANA, M.; MITRA, S. D.; KRITHIGA, N.; SHOMER, V. D.; BANERJEE, A.; BARBUDDHE, S. B.; PRABHUDAS, K.; RAHMAN, H. Molecular characterization of Streptococcus agalactiae and Streptococcus uberis isolates from bovine milk. Tropical Animal Health Production, Cambridge, v. 44, n. 8, p. 1981-1992, 2012.

SINGH, A.; GOERING, R. V.; SIMJEE, S.; FOLEY, S. T.; ZERVOS, M. J. Application of molecular techniques to the study of hospital infection. Clinical Microbiology Reviews, Washington, v. 19, n. 8, p. 512-530, 2006.

VLIEGHER, S. D.; FOX, L. K.; PIEPERS, S.; MCDOUGALL, S.; BARKEMA, H. W. Invited review: mastitis in dairy heifers: nature of the disease, potential impact, prevention, and control. Journal of Dairy Science, Champaign, v. 95, n. 3, p. 1025-1040, 2012.

WANG, L.; CHEN, W.; ZHANG, L.; ZHU, Y. Genetic diversity of Streptococcus uberis isolates from dairy cows with subclinical mastitis in Southern Xinjiang Province, China. The Journal of General And Applied Microbiology, Tóquio, v. 59, n. 4, p. 287-293, 2013.

WANG, S. M.; DEIGHTON, M.; CAPSTICK, J. A.; GERRATY, N. Epidemiological typing of bovine streptococci by pulsed-field gel electrophoresis. Epidemiology and Infection, Cambridge, v. 123, n. 3, p. 317-324, 1999.

WARD, P. N.; HOLDEN, M. T. G.; LEIGH, J. A.; LENNARD, N.; BIGNELL, A.; BARRON, A.; CLARK,
L.; QUAIL, M. A.; WOODWARD, J.; BARRELL, B. G.; EGAN, S. A.; FIELD, T. R.; MASKELL, D.; KEHOE, M.; DOWSON, C. G.; CHANTER, N.; WHATMORE, A. M.; BENTLEY, S. D.; PARKHILL, J. Evidence for niche adaptation in the genome of the bovine pathogen Streptococcus uberis. BMC Genomics, Londres, v. 10, n. 54, p. 1-17, 2009.

WARD, P. N.; LEIGH, J. A. Genetic analysis of Streptococcus uberis plasminogen activators. Indian Journal of Medicine Research, Cantt, v. 119, p. 136-140, 2004.

WATTS, J. L. Characterization and identification of streptococci isolated from bovine mammary glands. Journal of Dairy Science, Champaign, v. 71, n. 6, p. 1616-1624, 1988.

YUAN, Y.; DEGO, O. K.; CHEN, X.; ABADIN, E.; CHAN, S.; JORY, L.; KOVACEVIC, S.; ALMEIDA, R. A.; OLIVER, S. P. Conservation of Streptococcus uberis adhesion molecule and the sua gene in strains of Streptococcus uberis isolated from geographically diverse areas. Journal of Dairy Science, Champaign, v. 97, n. 12, p. 7668-7673, 2014.

ZADOKS, R. N.; GILLESPIE. B. E.; BARKEMA, H. W.; SAMPIMON, O. C.; OLIVER, S. P.; SCHUKKEN, Y. H. Clinical, epidemiological and molecular characteristics of Streptococcus uberis infections in dairy herds. Epidemiology Infection, Cambridge, v. 130, n. 2, p. 335-349, 2003.

ZADOKS, R. N.; MIDDLETON, J. R.; MCDOUGALL, S.; KATHOLM, J.; SCHUKKEN, Y. H. Molecular epidemiology of mastitis pathogens of dairy cattle and comparative relevance to humans. Journal Mammary Gland Biology and Neoplasia, Cambridge, v. 16, n. 4, p. 357-372, 2011. 
